\title{
Fighting cancer through an informed society
}

\author{
Prashant Mehta ${ }^{1}$, Pranjit Santonu Bhajoni ${ }^{2}$, Swati Pabbi Mehta ${ }^{3}$ \\ ${ }^{1}$ Unit Head Department of Medical Oncology/Hematoncology/BMT Asian Institute of Medical Sciences, Faridabad, Haryana, ${ }^{2}$ Department of \\ Pharmacology, Ram Manohar Lohia Medical College and Hospital, New Delhi, ${ }^{3}$ Department of Pathology, Sardar Patel Medical College, Bikaner, \\ Rajasthan, India
}

\section{A B S T R A C T}

Social perceptions play an extremely important role in the lives of cancer patients and survivors. Society is a machinery which can dictate the behavioral pattern of a patient, the kind of treatment he/she seeks or believes in, and the treatment he/she finally takes. Proper education of the society, in general, with regard to various aspects of cancer and its treatment can make things easier for patients, their families and the treating physicians alike. False social beliefs create unsurmountable hurdles for both patients and their families. When families of cancer patients visit a doctor, very often they tend to describe the experience of one or more of their close or distant family members with cancer. They start reliving the same experience if it was bad, or they may develop a false sense of security about the curability if it was good. In both situations, it becomes difficult for them to understand that each cancer is different from the other, cancer being a heterogenous disease. Moreover, what the patients and their families hear from friends and their social support system about cancer in general makes them depressed, anxious, and vulnerable. The information they get from the Internet and print media is mostly unregulated and may present extreme views which compound their problems. In this review, we have analyzed some of the common perceptions and myths which we come across in clinical practice and have presented scientific data to refute or support these beliefs wherever suitable.

Key words: Cancer, myths, social perceptions, society

\section{INTRODUCTION}

Society is a machinery which if well-informed can serve as a solution to several problems of an individual while if ill-informed and misguided can increase an individual's problems manyfold. Cancer is an individual problem but is heavily influenced by social perceptions. ${ }^{[1]}$ It has always been regarded as some sort of a taboo, and sometimes, people link it to a human's deeds in the present or past life. Human beings can react in strange ways to something they do not understand fully and may devise any kind of explanations to make it sound easier and less overbearing to the mind. ${ }^{[2]} \mathrm{A}$ diagnosis of

\begin{tabular}{|l|l|}
\hline \multicolumn{2}{|c|}{ Access this article online } \\
\hline Quick Response Code: & Website: \\
\hline & www.josh.net \\
\hline & \\
\hline
\end{tabular}

cancer is a huge burden on the affected family and the society as a whole. Hence, informing the society about what is true and what is questionable about cancer and its treatment is extremely important to counter the challenges posed by it. ${ }^{[3]}$ Through this article, we wish to focus on the common myths associated with cancer and its treatment. Although the topic is extensive, we as clinicians would be focusing on the common queries we face in daily practice.

\begin{abstract}
This is an open access article distributed under the terms of the Creative Commons Attribution-NonCommercial-ShareAlike 3.0 License, which allows others to remix, tweak, and build upon the work non-commercially, as long as the author is credited and the new creations are licensed under the identical terms.
\end{abstract}

For reprints contact: reprints@medknow.com

How to cite this article: Mehta P, Bhajoni PS, Mehta SP. Fighting cancer through an informed society. J Soc Health Diabetes 2016;4:57-66.

Corresponding Author: Dr. Prashant Mehta MD, DM (AIIMS, New Delhi), European Society for Medical Oncology Certifed, Unit Head Medical Oncology/Hematoncology/BMT Asian Institute of Medical Sciences, Faridabad, Haryana, India. E-mail: prashantcipher7@gmail.com 
There was a time when the doctor announcing a diagnosis of cancer to a patient meant that he was pronouncing a death sentence. It is no longer so.

\section{WHAT IS "CURE"?}

Cancer is a heterogeneous disease; the only thing common to all cancers is abnormal cell growth, else each cancer is different from the other [Table 1]. The survival and treatment strategies defined for pancreatic cancer cannot be compared to the same parameters for breast cancer. Similarly, the survival and treatment for acute myeloid leukemia cannot be compared to Hodgkin lymphoma. Even within the same disease, the survival can vary drastically..$^{[4]}$ A "luminal A" type of breast cancer, which is hormone receptor positive, is very different from a triple negative (hormone receptor negative and Her 2 neu negative) breast cancer as regards the biological behavior and treatment strategies. ${ }^{[5]}$

When families of cancer patients visit a doctor, very often they tend to describe the experience of one or more of their close or distant family member with cancer. They start reliving the same experience if it was bad, or they may develop a false sense of security about the curability if it was good. In both situations, it becomes difficult for them to understand that each cancer is different from the other. No two patients are the same and no two cancers are the same. ${ }^{[6]}$ Therapy has to be individualized in every case based on the pathology, general condition (Eastern cooperative oncology group performance status), organ function, molecular targets available, comorbidities, age, gender, ethnicity, socioeconomic status, compliance, tolerability, and pharmacogenomic profile. ${ }^{[7]}$

Similarly, "cure" can mean different things for different cancers and different patients. A 70-year-old patient who develops chronic lymphocytic leukemia (CLL) may actually never die of CLL but may die due to an unrelated cause. Further, many patients with CLL do not require any treatment late into the course of disease. Patients with stage 4 colorectal cancer may still get cured while the same cannot be said of lung cancer. ${ }^{[8]}$

The diagnosis of cancer is still a traumatic experience. Patients are shattered psychologically, lose belief in themselves and are often doubtful of therapeutic outcomes. In such a scenario they need the kindness and counseling a good clinician can provide. During this time of despair, they turn to anything, any source of information, any kind of hope that is provided by laymen, or glitzy advertisements in electronic media, paper, pamphlets claiming to cure the disease with miraculous drugs or herbs. ${ }^{[34]}$ Add to that, recollections of things that they may have heard about cancers in general in the society, the variety of opinions thrust on them by their kins, neighbors, friends, etc., and some bad experiences with cancer in someone they knew, it becomes a gargantuan task for the treating physician to take away the ugly perceptions which patients already have before they come to seek treatment and advise. Doubtless, this period is confusing to most patients and their families. Here, we look at some of the myths associated with cancer and chemotherapy which we commonly get to hear.

\section{General Perception of the Disease}

- Cancer is incurable and diagnosis of cancer is equivalent to a death sentence

Cancer is not a death sentence. Some very aggressive cancers such as pancreatic cancer are considered incurable if advanced. ${ }^{[30]}$ Many cancers (retinoblastoma of childhood, choriocarcinoma and other germ cell tumors, Hodgkin lymphoma, acute lymphoblastic leukemia) are completely curable. ${ }^{[10,12,14,35]}$ Most of the common cancers have seen quite a jump in 10-year

\begin{tabular}{|c|c|c|}
\hline $\begin{array}{l}\text { Cancers which can be completely } \\
\text { eradicated }{ }^{[9-14]}\end{array}$ & $\begin{array}{l}\text { Cancers which can linger on without threatening } \\
\text { life for years (indolent cancers) } \\
{\left[{ }^{[9,15-24]}\right.}\end{array}$ & $\begin{array}{l}\text { Cancers which may be rapidly } \\
\text { life- threatening and generally } \\
\text { have a short survival }\end{array}$ \\
\hline $\begin{array}{l}\text { Prostate cancer } \\
\text { Thyroid cancer } \\
\text { Testicular tumors } \\
\text { Melanoma } \\
\text { Breast cancer } \\
\text { Retinoblastoma } \\
\text { Wilms tumor } \\
\text { Hodgkin lymphoma } \\
\text { Diffuse large B-cell lymphoma } \\
\text { Acute lymphoblastic leukemia in children }\end{array}$ & $\begin{array}{l}\text { Chronic lymphocytic leukemia/small lymphocytic } \\
\text { lymphoma) } \\
\text { Marginal zone lymphoma } \\
\text { Follicular B-cell indolent type } \\
\text { Waldenstrom macroglobulinemia } \\
\text { Metastatic prostate cancer } \\
\text { Follicular dendritic cell sarcoma } \\
\text { Kaposi sarcoma } \\
\text { Mantle-cell lymphoma (indolent subtype) } \\
\text { Low-grade neuroendocrine tumors }\end{array}$ & $\begin{array}{l}\text { Neuroendocrine carcinomas } \\
\text { Mantle-cell lymphoma } \\
\text { Primary central nervous system } \\
\text { lymphoma (rapidly life-threatening } \\
\text { but can still be cured) } \\
\text { Mesothelioma } \\
\text { Small cell lung cancer } \\
\text { Pancreatic cancer } \\
\text { Cancer of the gallbladder } \\
\text { High-grade glioma } \\
\text { Acute myeloid leukemia (rapidly } \\
\text { life-threatening but can still be cured) }\end{array}$ \\
\hline
\end{tabular}


life expectancy rates. For example, 10-year survival rate for one of the most common cancers, cancer of the prostate, is $98 \% .^{[36]}$

- We have made no progress in fighting cancer We have made tremendous progress in cancer therapy. For breast cancer, 10-year survival rates were $40 \%$ during 1971-1972 and have increased to $78 \%$ in the present time. ${ }^{[37]}$

- Cancer is genetic, so nothing can prevent it whether or not one is diagnosed

Only about $5-10 \%$ of all cancers result directly from genetic defects (called mutations) inherited from a parent. The early detection of cancer improves survival. Early diagnosis means that the spread of cancer from its primary site to distant organs can be prevented by early intervention. ${ }^{[38,39]}$

- Cancer is God's punishment

Cancer is not God's punishment to humankind. In $5-10 \%$ of all cancers, it is the result of genetic defects (harmful mutations) inherited from a parent. In all other cases, it is because of the interaction of the individual with the environment and genes (harmful sporadic mutations). ${ }^{[38,39]}$

- Cancer is a man-made, modern disease? Early people had access to pure, uncontaminated water, pure food, pure air, and that is why they did not have cancer Cancer is not a man-made disease. It was described thousands of years ago by Egyptian and Greek physicians. Even dinosaurs had cancer. ${ }^{[40-42]}$

- Cancer is contagious

Cancer is not contagious. Some cancers, such as cancers following organ or tissue transplantation, cancers occurring after Helicobacter pylori (a bacteria), or human papillomavirus (a virus) infection, have an infectious etiology, but the cancer per se is not contagious. For example, transplant-related cancers may occur in 2 cases out of 10,000 organ transplants. ${ }^{[43]}$ For transmissible cancers, the reader is directed to NCI (National Cancer Institute) website..$^{[44,45]}$

- Cancer is a fungus - and sodium bicarbonate is the cure

Cancer is not a fungus and sodium bicarbonate is not a cure for any type of cancers. ${ }^{[46,47]}$

\section{FOOD AND FOOD PRODUCTS}

- Acidic diets cause cancer

Acidic diets do not cause cancer. This misconception arose from the study of cancer cells in the laboratory. Cancer cells were found to produce an acidic microenvironment around themselves by producing acidic molecules. This misconception led to the belief that acidic diets cause cancer and alkaline diets can cure cancer. ${ }^{[48]}$ However, the human body is always alkaline, and cancer cells thrive in the alkaline human body. ${ }^{[49]}$ This alkaline $\mathrm{pH}$ is maintained by the kidneys within a very narrow and healthy range around 7.4. If acidic food is ingested, the urine becomes acidic and the excess acidity is get rid of. Similarly, if alkaline food is ingested, the urine becomes alkaline and the excess alkalinity is taken care of. Acidic or alkaline food cannot change $\mathrm{pH}$ of the body if the kidneys are functioning normally. Acidic or alkaline diets cannot change anything, neither the body's slight alkalinity nor the acidic microenvironment around the cancer cells. ${ }^{[49,50]}$

- Cancer has a sweet tooth and eating sugar makes cancer worse

The answer is, may be true. Sugary diets (diets rich in simple sugars) may be associated with an increased risk of pancreatic and colon cancers. ${ }^{[51-53]}$ Obesity is also associated with an increased risk of cancer, and weight should be kept within normal range with adequate exercise. ${ }^{[54]}$

- Artificial sweeteners cause cancer

The short answer is no. There are many different artificial sweeteners. Saccharin and aspartame have been shown to cause increased number of cancers in rats when fed in high amounts. Others, such as acesulfame, sucralose, neotame, and tagatose did not show the same tendency in animals. However, no artificial sweetener has shown any increased cancer risk in humans. Stevia/rebaudioside A is generally not recommended. ${ }^{[55,56]}$

- Antiperspirants or deodorants cause cancer (especially breast cancer)

The answer is no. In 2002, a study was done with 813 women with breast cancer and 793 women without. The results did not show any increased risk for breast cancer in women who reported using an underarm antiperspirant or deodorant. The study also showed no increased breast cancer risk for women who reported using a blade razor and an underarm antiperspirant or deodorant or for women who reported using an underarm antiperspirant or deodorant within $1 \mathrm{~h}$ of shaving with a blade razor. However, some other poorly designed studies showed conflicting results. ${ }^{[57]}$

- Hair dye use increases the risk of cancer

The short answer is no. Some studies have shown an increased risk of developing bladder cancer with the use of earlier permanent type of dyes (dyes manufactured before the 1980s). However, no such association has been found with the use of modern dyes. ${ }^{[58,59]}$ 
- Drugs used in treatment of diseases can cause cancer The answer is partially true. Evidence is there that hormone replacement therapy given to elderly women, naphthalene, anticancer drugs such as busulfan, chlorambucil, and thiotepa, some ointments such as Elidel (active ingredient pimecrolimus) used for atopic dermatitis may cause cancer. Patients should talk to their doctors if they are in doubt. ${ }^{[60-62]}$

- Alcohol is good for cancer/alcohol is bad for cancer Alcohol has been associated with cancer. Certain substances in red wine, such as resveratrol, have anticancer properties in the laboratory. Grapes, raspberries, peanuts, and some other plants also contain resveratrol. However, there is no evidence that resveratrol is effective in preventing or treating cancer in humans. People should not drink alcohol to get resveratrol. ${ }^{[63-65]}$

- Herbal products/superfoods can cure cancer Use of herbal products is generally not advocated by doctors. There is no conclusive scientific evidence to prove that herbal supplements, drugs, are effective in cancer cure or mitigation of cancer symptoms. They can lead to dangerous interactions with the chemotherapy drugs causing the principal drug to be either ineffective or more toxic. Many people use high-dose antioxidant supplements thinking that they are only going to protect normal cells, but antioxidants such as Vitamin E may protect both normal and tumor cells and scientific data also support this. The silver lining is, while many herbs have been shown to interfere with chemotherapy, some may actually improve its efficacy. It is not known which herbal or other supplements are helpful or harmful and in what quantities. Adequate data are lacking. For this reason, doctors do not advise taking herbal drugs or supplements with proven anticancer drugs. ${ }^{[6]]}$

- There is a miracle cancer cure and Big Pharma is suppressing it

The answer is, false and actually absurd. If there was any such a treatment available, the people in the know such as the scientists, researchers, and rich people would never die of cancer. Moreover, that would mean that they are dying every year (many doctors and scientists die of cancer) and sacrificing the lives of their loved ones to keep the cure a secret. ${ }^{[67-70]}$

- Sharks do not get cancer and shark oil, shark gelatin, and shark cartilage are the cure for cancer

It is a hoax. Sharks do get cancer. Sharks Don't Get Cancer (subtitle: How Shark Cartilage Could Save Your Life) is a 1992 book written by I. William Lane and Linda Comac and published by Avery Publishing. William Lane used to sell extracts of shark cartilage as a treatment for cancer. When one comes to think of it, it becomes obvious that he first wrote the book claiming that sharks do not get cancer, then went on to sell shark and shark products. In 2004, Dr. Ostrander et al. from the University of Hawaii published a survey of the Registry for Tumors in Lower Animals. Already in collection, they found 42 tumors in Chondrichthyes species (cartilaginous fish that includes sharks, skates, and rays). These included at least 12 malignant tumors and tumors throughout the body. Two sharks had multiple tumors. ${ }^{[71-74]}$

\section{Cell Phone and Electronic Equipiment}

- Cell phones, power lines, computer use cause cancer The short answer is no. The International Agency for Research on Cancer (IARC) is a part of the World Health Organization. Its major goal is to identify causes of cancer. The IARC has classified radiofrequency fields as "possibly carcinogenic to humans," based on limited evidence of a possible increase in risk for brain tumors among cell phone users and inadequate evidence for other types of cancer.

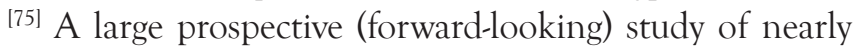
800,000 women in the UK examined the risk of developing brain tumors over a 7-year period in relation to self-reported cell phone use at the start of the study. This study found no link between cellphone use and brain tumors overall or several common brain tumor subtypes, but it did find a possible link between long-term cell phone use and acoustic neuromas (It is a benign tumor not cancer). ${ }^{\text {[76] }}$

Cordless telephones emit less energy than cell phones. ${ }^{[77]}$ Several studies have analyzed the combined data from multiple studies of power line exposure and childhood leukemia. A pooled analysis of nine studies reported a twofold increase in risk of childhood leukemia among children with exposures of $0.4 \mu \mathrm{T}$ ( $\mu \mathrm{T}$ is a unit of radiation energy) or higher. Less than $1 \%$ of the children in the studies experienced this level of exposure. ${ }^{[78]} \mathrm{A}$ meta-analysis of 15 studies observed a 1.7-fold increase in childhood leukemia among children with exposures of $0.3 \mu \mathrm{T}$ or higher. A little more than $3 \%$ of children in the studies experienced this level of exposure. ${ }^{[79]}$

More recently, a pooled analysis of seven studies published after 2000 reported a 1.4-fold increase in childhood leukemia among children with exposures of $0.3 \mu \mathrm{T}$ or higher. However, less than one-half of $1 \%$ of the children in the studies experienced this level of exposure. ${ }^{[80]}$

For the two pooled studies and the meta-analysis, the number of highly exposed children was too small to 
provide stable estimates of the dose-response relationship. This means that the findings could not be interpreted to reflect linear increases in risk, a threshold effect at 0.3 or $0.4 \mu \mathrm{T}$, or no significant increase. ${ }^{[78-80]}$

For a $400 \mathrm{kV}$ power line, the exposure level falls below $0.3 \mu \mathrm{T}$ at a $600 \mathrm{~m}$ distance. For reference, in homes not located near power lines, this background field may be up to about $0.2 \mu \mathrm{T}^{\text {[81] }}$

Exposure from electrical appliances contributes less to a person's total exposure to magnetic fields because most appliances are used for only short periods of time. ${ }^{[82]}$

Exposure to $\mathrm{Wi}-\mathrm{Fi}$ is not considered to pose any health risk to humans. ${ }^{[83]}$ No data on relation between exposure to cell phone base stations and cancer are available. ${ }^{[84]}$ Prolonged computer use can cause spinal problems such as backache, eyestrain, obesity, and sleep disturbance. No adequate data on computer use and increase in cancer incidence are available. Laptop computers if held close to the body exposes the body to significantly higher radiation compared to desktop computers. ${ }^{[85]}$

\section{All OR NONe MYTHS}

- Does patient's attitude (positive or negative) determine his/her risk of, or likely recovery from, cancer?

Positive attitude helps in dealing with cancer and its fallout. A person with positive attitude will be healthier compared with a person with negative attitude even though both may have same cancer at the same clinical stage. However, positive attitude has no effect on overall survival. ${ }^{[86]}$

- If someone in the patient's family has cancer, he/she is likely to get cancer. If no one in the patient's family has had cancer, does that mean he/she is risk-free? A person who has no family members with cancer can develop cancer. Contrarily, a person who has many family members with cancer may not have cancer and can live to ripe old age. ${ }^{[87]}$

\section{BREAST CANCER MythS}

Any type of cancer is a psychological blow to the patient. Breast cancer especially is a huge blow to women though men can also have breast cancer.

- Men do not get breast cancer; it affects women only Men do get breast cancer. Approximately 1\% of all breast cancer cases are found in men. Men have less breast cancer because men have less breast tissue compared to women. Men also have less amount of estrogen in the body, excess amount of which may drive breast cancer growth. ${ }^{[88]}$

- Finding a lump in breast means it is a breast cancer The answer is no. A lump may indicate a benign (noncancerous) condition such as fat necrosis and mastitis (inflammation of the breast). ${ }^{[89]}$

- Regular mammograms prevent breast cancer Regular mammograms do not prevent breast cancer. Mammograms have no relation whatsoever with occurrence of breast cancer but can aid in early diagnosis. Mammograms can only detect whether any benign or cancerous lesion (which are detectable by mammogram; there are some conditions of the breast which are not detectable by mammogram or magnetic resonance imaging [MRI]) is in the breast. ${ }^{[90]}$

- A mammogram can cause breast cancer to spread Mammograms do not make breast cancer spread. ${ }^{[00]}$

- If one has a family history of breast cancer, one will develop breast cancer

Cancer or breast cancer depends on many factors. Having a family member does not mean one is going to get breast cancer. For only one first-degree female relative with breast cancer, the relative risk is slightly more than the average rate in the general population. However, if the number of first-degree relatives with breast cancer is more than one, the risk increases dramatically and screening is recommended in such

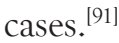

- Breast cancer is contagious

The answer is no. Breast cancer is not contagious. ${ }^{[92]}$

- If mutation in BRCA1 or BRCA2 gene is detected in DNA, one will definitely develop breast cancer Only deleterious mutations of BRCA1 or BRCA2 lead to an increased risk of breast cancer. BRCA1 or BRCA2 genes can have some mutations that in fact decrease the risk of breast cancer. Approximately $50-65 \%$ of women born with a deleterious mutation in BRCA1 will develop breast cancer, and 35-46\% will develop ovarian cancer by the age of 70 . Approximately $40-57 \%$ of women with a deleterious mutation in BRCA2 will develop breast cancer, and $13-23 \%$ will develop ovarian cancer by the age of 70 . Conversely, $35-50 \%$ of women born with a deleterious mutation in BRCA1 will not develop breast cancer, and 54-66\% will not develop ovarian cancer by the age of 70 . Moreover, approximately 43-60\% of women with a deleterious mutation in BRCA2 will not develop breast cancer, and $77-87 \%$ will not develop ovarian cancer by the age of $70 .{ }^{[93]}$

- MRI is better than mammography because it finds more cancer

The answer is yes and no. MRI is more sensitive than mammography but also gives more false positive results. Mammography is less sensitive but gives less false 
positive results. Both MRI and mammography may miss some cancers. Further, mammography is cheaper. All these reasons make mammography the gold standard and MRI, a supplemental test at present. Therefore, as a routine procedure, doctors advise mammography though MRI also has its place in the diagnosis of breast cancer in high-risk patients (e.g. patients with first-degree relatives with breast cancer, BRCA mutants, history of radiation to chest wall). ${ }^{[94]}$

- In terms of survival, removing the entire breast is better than just cutting cancer out and getting radiation Mastectomy (removal of the whole breast) and breast conservation surgery followed by radiation are equivalent in terms of overall survival and disease-free survival for breast cancers $<4 \mathrm{~cm}$ in diameter. Removal of the whole breast is not superior to lumpectomy/breast conservation surgery, followed by radiation for small cancers. ${ }^{[95]}$

- The risk of developing breast cancer cannot be reduced Breast cancer risk can be reduced with these healthy habits: ${ }^{[96]}$

o Healthy weight

o Regular exercise

o Adequate nighttime sleep

o Cessation of drinking or limiting alcoholic drinks to no more than $1 /$ day

o Avoiding exposure to carcinogens

o Limiting exposure to radiation from medical imaging tests such as X-rays, computed tomography scans, and positron emission tomography scans if not medically necessary

o Consulting once doctor if a person is taking, or have been advised, hormone replacement therapy or oral contraceptives (birth control pills)

o Breastfeeding if possible

o Talking to doctors more about risk factors for breast cancer and ways to reduce them.

- Bras cause breast cancer

Bra wearing does not cause breast cancer. No aspect of bra wearing, including bra cup size, average number of hours/days worn, wearing a bra with an underwire, or age of initiating wearing a bra, was associated with risks of either invasive ductal carcinoma or invasive lobular carcinoma. ${ }^{[97]}$

- Larger breasts are associated with an increased risk of breast cancer

Larger breasts are not associated with an increased risk of breast cancer. However, obesity is associated with increased breast cancer risk. What this means is that a woman with large breasts but with no obesity has the same breast cancer risk as that of the general population. However, large breasts also present its own problems, viz., small tumors may be missed on breast examination, mammography, or MRI or ultrasonography. ${ }^{[98]}$

\section{THERAPY}

- Cancer is extremely painful

Some cancers are painful, and some are not. Suitable drugs are available that can treat cancer pain. ${ }^{[99]}$

- If the physician prescribes chemotherapy, it means the illness is terminal

The answer is, false. For breast cancer, which almost always requires chemotherapy during treatment, 10-year survival rates were 40\% during 1971-1972, which has now increased to $78 \%$. $^{[36,37]}$

- Chemotherapy is painful, chemotherapy causes unbearable nausea, and chemotherapy drugs are always toxic

Chemotherapy is not painful. Some chemotherapy drugs cause nausea. Some chemotherapy drugs are toxic. However, cancer chemotherapy has improved tremendously over the years. It has increased overall survival, disease-free survival while at the same time, becoming less toxic. ${ }^{[100]}$ Modern chemotherapy is not a single drug therapy any longer. Multiple drugs are used. If the primary chemotherapy drug is likely to cause nausea, powerful antiemetics (drugs that prevent nausea and vomiting) are used. Aprepitant and palonosetron are newer drugs which are extremely effective in suppressing chemotherapy-induced nausea and vomiting to almost negligible levels. ${ }^{[101,102]}$ When a tumor is killed by chemotherapy drugs, it may release large amounts of uric acid and give rise to symptoms of hyperuricemia which is harmful for the body, especially kidneys. It can be prevented by prophylactic use of rasburicase, a uric acid metabolizing enzyme. ${ }^{[103]}$ The current chemotherapy has not remained the same as it was in the 1940s. It has become so much easier on the patients with the least toxicity and maximum efficacy and has increased overall survival. It has also become easier on the doctors as the medicines can be given on a day-care basis and the patients can be sent home after getting the medicines during the day. ${ }^{104]}$

- Treatment of cancer is worse than the disease Treatment of cancer has been proven to be better than the disease. Treatment means longer disease-free, symptom-free, disability-free life. ${ }^{[105]}$

- Everybody loses their hair

Thirty-five percent patients do not lose their hair. Moreover, in majority of cases of hair loss, it grows back 4-6 months after stopping chemotherapy. ${ }^{[106]}$

- Immunity is compromised during chemotherapy 
Immunity may be compromised depending upon the cancer type, the drugs used. However, other drugs are used to mitigate the decreased immunity. ${ }^{[107]}$

- Chemotherapy is not worth it (too much pain, with no hope of recovery)

Chemotherapy is worth it. Pain if present can be treated with analgesics. Moreover, chemotherapy and other therapies for cancer have been steadily increasing the number of years a patient can live a disease-free healthy life. ${ }^{[36,37,90,94]}$

- One can be too old for cancer treatment Nobody is too old for chemotherapy. All parameters including patient's age are taken into consideration when chemotherapy is given. ${ }^{[108]}$

- Cancer treatment means that the patient is confined to the hospital and will not be able to live at home, work, or go about his/her usual activities. Chemotherapy will completely disrupt patient's life

Today's cancer treatment in majority of cases is administered on a day-care basis. This means that patients go home after the medicines have been given during the day and can enjoy doing almost whatever they want to do. Doctors generally advise rest for a day or two. Furthermore, chemotherapy is given in cycles. In the time between cycles, the patient is generally free to do what he/she likes. ${ }^{[104]}$

- A patient going through chemotherapy can contaminate others

The reverse is true. Adequate care should be taken so that the patient is not unnecessarily exposed to infection risk. ${ }^{[109,110]}$

- One cannot get pregnant during chemo/one will never be a father or mother again

One can get pregnant during chemo, but doctors advise against it because of the risk to the fetus. One can become a father or mother after chemotherapy is over. However, depending on cancer and drugs used, doctors may advise the patient for ova harvesting (for female patients) or sperm banking (for male patients). ${ }^{[111-113]}$

- Cancer surgery, tumor biopsy, needle biopsy causes cancer to spread in the body?

Cancer surgery, tumor biopsy, needle biopsy does not cause cancer to spread to other parts of the body. Cancer surgery is generally followed by other modalities of treatment such as radiation therapy or chemotherapy and any residual cancerous cells left in the body are killed. ${ }^{[114]}$

- People with cancer should "rest" as much as possible It is not necessary. Doctors generally advise rest only for a day or two. ${ }^{[115,116]}$

- Supplements and herbs can cure cancer
The answer is no. Only chemotherapy, surgery, radiation therapy, targeted therapy, and immunotherapy, or their combinations have been proven to cure cancer. The claims of herbal and other such alternative products have not been substantiated till now, and there is no clinical trial data to show that such therapies actually work in the real-world scenario. ${ }^{[11-119]}$

Financial support and sponsorship

Nil.

Conflicts of interest

There are no conflicts of interest.

\section{REFERENCES}

1. Robb KA, Simon AE, Miles A, Wardle J. Public perceptions of cancer: A qualitative study of the balance of positive and negative beliefs. BMJ Open 2014;4:e005434.

2. Gilbar O, Hevroni A. Counterfactuals, coping strategies and psychological distress among breast cancer patients. Anxiety Stress Coping 2007;20:383-92.

3. Mahal A, Karan A, Fan VY, Engelgau M. The economic burden of cancers on Indian households. PLoS One 2013;8:e71853.

4. Zellmer V, Zhang S. Evolving concepts of tumor heterogeneity. Cell Biosci 2014;4:69.

5. Haque R, Ahmed SA, Inzhakova G, Shi J, Avila C, Polikoff J, et al. Impact of breast cancer subtypes and treatment on survival: An analysis spanning two decades. Cancer Epidemiol Biomarkers Prev 2012;21:1848-55.

6. Christ GH, Messner C, Behar LC, editors. Handbook of Oncology Social Work: Psychosocial Care for People with Cancer. 19 Oxford University Press, Incorporated; 2015.

7. Veal GJ, Coulthard SA, Boddy AV. Chemotherapy individualization. Invest New Drugs 2003;21:149-56.

8. Byrd JC. Introduction to a series of reviews on chronic lymphocytic leukemia. Blood 2015;126:427.

9. United States Cancer Statistics; 2016. Available from: https://www. nccd.cdc.gov/uscs/SurvivalData.aspx. [Last cited on 2016 Jul 22].

10. Park SJ, Woo SJ, Park KH. Incidence of retinoblastoma and survival rate of retinoblastoma patients in Korea using the Korean National Cancer Registry database (1993-2010). Invest Ophthalmol Vis Sci 2014;55:2816-21.

11. Davidoff AM. Wilms' tumor. Curr Opin Pediatr 2009;21:357-64.

12. Koren J, Trnený M. Hodgkin ×s lymphoma - The treatment approaches development and current trends. Klin Onkol 2015;28 Suppl 3:3S87-94.

13. Székely E, Hagberg O, Arnljots K, Jerkeman M. Improvement in survival of diffuse large B-cell lymphoma in relation to age, gender, International Prognostic Index and extranodal presentation: A population based Swedish Lymphoma Registry study. Leuk Lymphoma 2014;55:1838-43.

14. Trigg ME, Sather HN, Reaman GH, Tubergen DG, Steinherz PG, Gaynon PS, et al. Ten-year survival of children with acute lymphoblastic leukemia: A report from the Children's Oncology Group. Leuk Lymphoma 2008;49:1142-54.

15. Brenner $\mathrm{H}$, Gondos A, Pulte D. Trends in long-term survival of patients with chronic lymphocytic leukemia from the 1980s to the early $21^{\text {st }}$ century. Blood 2008;111:4916-21.

16. Yee K, O’Brien S. Chronic Iymphocytic leukemia/small 
lymphocytic lymphoma. In: O'Brien S, Vose J, Kantarjian H, editors. Management of Hematologic Malignancies. $1^{\text {st }}$ ed. Cambridge: Cambridge University Press; 2010. p. 81-102.

17. Olszewski AJ, Castillo JJ. Survival of patients with marginal zone lymphoma: Analysis of the surveillance, epidemiology, and end results database. Cancer 2013;119:629-38.

18. Arcaini L, Rattotti S, Gotti M, Luminari S. Prognostic assessment in patients with indolent B-cell lymphomas. ScientificWorldJournal 2012;2012:107892.

19. Oza A, Rajkumar S. Waldenstrom macroglobulinemia: Prognosis and management. Blood Cancer J 2015;5:e296.

20. Tangen CM, Faulkner JR, Crawford ED, Thompson IM, Hirano D, Eisenberger $\mathrm{M}$, et al. Ten-year survival in patients with metastatic prostate cancer. Clin Prostate Cancer 2003;2:41-5.

21. Li L, Shi YH, Guo ZJ, Qiu T, Guo L, Yang HY, etal. Clinicopathological features and prognosis assessment of extranodal follicular dendritic cell sarcoma. World J Gastroenterol 2010;16:2504-19.

22. Franceschi S, Arniani S, Balzi D, Geddes M. Survival of classic Kaposi's sarcoma and risk of second cancer. $\mathrm{Br} \mathrm{J}$ Cancer 1996;74:1812-4.

23. Furtado M, Rule S. Indolent mantle cell lymphoma. Haematologica 2011;96:1086-8.

24. Van Eeden S, Quaedvlieg PF, Taal BG, Offerhaus GJ, Lamers CB, Van Velthuysen ML. Classification of low-grade neuroendocrine tumors of midgut and unknown origin. Hum Pathol 2002;33:1126-32.

25. Modrek AS, Hsu HC, Leichman CG, Du KL. Radiation therapy improves survival in rectal small cell cancer - Analysis of surveillance epidemiology and end results (SEER) data. Radiat Oncol 2015;10:101.

26. Bernard $M$, Gressin R, Lefrère $F$, Drénou B, Branger B, Caulet-Maugendre $\mathrm{S}$, et al. Blastic variant of mantle cell lymphoma: A rare but highly aggressive subtype. Leukemia 2001;15:1785-91.

27. Schorb E, Kasenda B, Atta J, Kaun S, Morgner A, Hess G, et al. Prognosis of patients with primary central nervous system lymphoma after high-dose chemotherapy followed by autologous stem cell transplantation. Haematologica 2013;98:765-70.

28. Musk AW, Olsen N, Alfonso H, Reid A, Mina R, Franklin P, et al. Predicting survival in malignant mesothelioma. Eur Respir $\mathrm{J}$ 2011;38:1420-4.

29. Ramlov A, Tietze A, Khalil AA, Knap MM. Prophylactic cranial irradiation in patients with small cell lung cancer. A retrospective study of recurrence, survival and morbidity. Lung Cancer 2012;77:561-6.

30. Johnson C. Prognosis in pancreatic cancer. Lancet 1997;349:1027.

31. Konstantinidis I, Deshpande V, Genevay M, Ferrone C. Trends in presentation and survival for gallbladder cancer during a period of more than 4 decades. Arch Surg 2009;144:441.

32. Mathiesen T, Peredo I, Lönn S. Two-year survival of low-grade and high-grade glioma patients using data from the Swedish Cancer Registry. Acta Neurochir 2010;153:467-71.

33. Bennett JM, Young ML, Andersen JW, Cassileth PA, Tallman MS, Paietta E, et al. Long-term survival in acute myeloid leukemia: The Eastern Cooperative Oncology Group experience. Cancer 1997;80 11 Suppl: 2205-9.

34. Onuigbo WIB. Human Behavior in Cancer Quackery: Historical Review. Int J Neurorehabilitation Eng 2016;3:196.

35. Goto S, Ino K, Mitsui T, Kikkawa F, Suzuki T, Nomura S, et al. Survival rates of patients with choriocarcinoma treated with chemotherapy without hysterectomy: Effects of anticancer agents on subsequent births. Gynecol Oncol 2004;93:529-35.

36. Li J, Djenaba JA, Soman A, Rim SH, Master VA. Recent trends in prostate cancer incidence by age, cancer stage, and grade, the
United States, 2001-2007. Prostate Cancer 2012;2012:691380.

37. Breast Cancer Survival Statistics. UK: Cancer Research; 2015. Available from: http://www.cancerresearchuk.org/ health-professional/cancer-statistics/statistics-by-cancer-type/ breast-cancer/survival\#heading-Two. [Last cited on 2016 Jul 06].

38. Anand P, Kunnumakkara AB, Sundaram C, Harikumar KB, Tharakan ST, Lai OS, et al. Cancer is a preventable disease that requires major lifestyle changes. Pharm Res 2008;25:2097-116.

39. Ellis C. Inherited Cancer Syndromes. New York: Springer; 2011.

40. Cancer Incidence by Age. UK: Cancer Research; 2015. Available from: http://www.cancerresearchuk.org/health-professional/ cancer-statistics/incidence/age\# heading-Zero. [Last cited on 2016 Jul 06].

41. Binder M, Roberts C, Spencer N, Antoine D, Cartwright C. On the antiquity of cancer: Evidence for metastatic carcinoma in a young man from ancient Nubia (c 1200 BC). PLoS One 2014;9:e90924.

42. Natarajan $L$, Melott $A$, Rothschild $B$, Martin L. Bone cancer rates in dinosaurs compared with modern vertebrates. Trans Kansas Acad Sci 2007;110:155-8.

43. Bower M, Waxman J. Lecture Notes. Hoboken: John Wiley and Sons; 2011.

44. Lowy DR, Schiller JT. Reducing HPV-associated cancer globally. Cancer Prev Res (Phila) 2012;5:18-23.

45. Watari J, Chen N, Amenta PS, Fukui H, Oshima T, Tomita T, et al. Helicobacter pylori associated chronic gastritis, clinical syndromes, precancerous lesions, and pathogenesis of gastric cancer development. World J Gastroenterol 2014;20:5461-73.

46. Krcmery V Jr. Emerging fungal infections in cancer patients. J Hosp Infect 1996;33:109-17.

47. Rolston KV, Rodriguez S, Dholakia N, Whimbey E, Raad I. Pulmonary infections mimicking cancer: A retrospective, three-year review. Support Care Cancer 1997;5:90-3.

48. Kato Y, Ozawa S, Miyamoto C, Maehata Y, Suzuki A, Maeda T, et al. Acidic extracellular microenvironment and cancer. Cancer Cell Int 2013;13:89.

49. Bonjour JP. Nutritional disturbance in acid-base balance and osteoporosis: A hypothesis that disregards the essential homeostatic role of the kidney. Br J Nutr 2013;110:1168-77.

50. American Institute for Cancer Research (AICR) - EGEH: Busting Cancer Myths: Acidic Foods and Cancer Risks; 2016. Available from: http://www.preventcancer.aicr.org/site/News2?page $=\mathrm{Ne}$ wsArticle\&id=13914\&news_iv_ctrl $=0 \& a b b r=p r$. [Last cited on 2016 Jul 07].

51. Michaud DS, Liu S, Giovannucci E, Willett WC, Colditz GA, Fuchs CS. Dietary sugar, glycemic load, and pancreatic cancer risk in a prospective study. J Natl Cancer Inst 2002;94:1293-300.

52. Bostick RM, Potter JD, Kushi LH, Sellers TA, Steinmetz KA, McKenzie DR, et al. Sugar, meat, and fat intake, and non-dietary risk factors for colon cancer incidence in lowa women (United States). Cancer Causes Control 1994;5:38-52.

53. Dong JY, Qin LQ. Dietary glycemic index, glycemic load, and risk of breast cancer: Meta-analysis of prospective cohort studies. Breast Cancer Res Treat 2011;126:287-94.

54. De Pergola G, Silvestris F. Obesity as a major risk factor for cancer. J Obes 2013;2013:291546.

55. Gallus S, Scotti L, Negri E, Talamini R, Franceschi S, Montella M, et al. Artificial sweeteners and cancer risk in a network of case-control studies. Ann Oncol 2007;18:40-4.

56. Artificial Sweeteners and Cancer. National Cancer Institute; 2016. Available from: http://www.cancer.gov/about-cancer/ causes-prevention/risk/diet/artificial-sweeteners-fact-sheet. [Last cited on 2016 Jul 07].

57. Mirick D. Antiperspirant Use and the Risk of Breast Cancer. Cancer Spectr Knowl Environ 2002;94:1578-80. 
58. Harling M, Schablon A, Schedlbauer G, Dulon M, Nienhaus A. Bladder cancer among hairdressers: A meta-analysis. Occup Environ Med 2010;67:351-8.

59. Kelsh MA, Alexander DD, Kalmes RM, Buffler PA. Personal use of hair dyes and risk of bladder cancer: A meta-analysis of epidemiologic data. Cancer Causes Control 2008;19:549-58.

60. Printz C. Breast cancer risk associated with HRT varies. Cancer 2014;120:315.

61. Siegfried EC, Jaworski JC, Hebert AA. Topical calcineurin inhibitors and lymphoma risk: Evidence update with implications for daily practice. Am J Clin Dermatol 2013;14:163-78.

62. Berger TG, Duvic M, Van Voorhees AS, VanBeek MJ, Frieden IJ; American Academy of Dermatology Association Task Force. The use of topical calcineurin inhibitors in dermatology: Safety concerns. Report of the American Academy of Dermatology Association Task Force. J Am Acad Dermatol 2006;54:818-23.

63. Pöschl G, Seitz HK. Alcohol and cancer. Alcohol Alcohol 2004;39:155-65.

64. Nelson DE, Jarman DW, Rehm J, Greenfield TK, Rey G, Kerr WC, et al. Alcohol-attributable cancer deaths and years of potential life lost in the United States. Am J Public Health 2013;103:641-8.

65. Athar M, Back JH, Tang X, Kim KH, Kopelovich L, Bickers DR, et al. Resveratrol: A review of preclinical studies for human cancer prevention. Toxicol Appl Pharmacol 2007;224:274-83.

66. Ekor M. The growing use of herbal medicines: Issues relating to adverse reactions and challenges in monitoring safety. Front Pharmacol 2014;4:177.

67. Childs O. Don't Believe the Hype - 10 Persistent Cancer Myths Debunked. UK: Cancer Research; 2016. Available from: http://www.scienceblog. cancerresearchuk.org/2014/03/24/ dont-believe-the-hype- 10-persistent-cancer-myths-debunked/. [Last cited $2016 \mathrm{Jul}$ 07].

68. Bashford EF. Cancer, credulity, and quackery. Br Med J 1911;1:1221-30.

69. Nolan G. Analysis: The Notion of Deliberate Suppression of the Cure for Cancer. The Logical Libertarian ${ }^{\mathrm{TM}}$; 2016. Available from: https:// www.logicallibertarian.com/2016/05/26/analysis-the-notion-ofdeliberate-suppression-of-the-cure-for-cancer/. [Last cited on 2016 Jul 07].

70. Dawes L. "Just a quack who can cure cancer": John Braund, and regulating cancer treatment in New South Wales, Australia. Med Hist 2013;57:206-25.

71. Ostrander GK, Cheng KC, Wolf JC, Wolfe MJ. Shark cartilage, cancer and the growing threat of pseudoscience. Cancer Res 2004;64:8485-91.

72. Borucinska JD, Harshbarger JC, Bogicevic T. Hepatic cholangiocarcinoma and testicular mesothelioma in a wild-caught blue shark, Prionace glauca (L.). J Fish Dis 2003;26:43-9.

73. Macneil J. Shark cartilage sinks in phase III lung cancer trial. Skin Allergy News 2007;38:48.

74. Vickers A. Alternative cancer cures: "Unproven" or "disproven"? CA Cancer J Clin 2004;54:110-8.

75. Research Groups - Section of Environment and Radiation; 2016. Available from: http://www.iarc.fr/en/research-groups/ENV/ publications2.php. [Last cited on $2016 \mathrm{Jul}$ 07].

76. Benson VS, Pirie K, Schüz J, Reeves GK, Beral V, Green J; Million Women Study Collaborators. Mobile phone use and risk of brain neoplasms and other cancers: Prospective study. Int J Epidemiol 2013;42:792-802.

77. IARC. Non-ionizing Radiation, Part 2. Lyon: IARC; 2014.

78. Ahlbom A, Day N, Feychting M, Roman E, Skinner J, Dockerty $\mathrm{J}$, et al. A pooled analysis of magnetic fields and childhood leukaemia. Br J Cancer 2000;83:692-8.

79. Greenland S, Sheppard AR, Kaune WT, Poole C, Kelsh MA. A pooled analysis of magnetic fields, wire codes, and childhood leukemia. Childhood Leukemia-EMF Study Group. Epidemiology 2000;11:624-34.

80. Kheifets L, Ahlbom A, Crespi CM, Draper G, Hagihara J, Lowenthal RM, et al. Pooled analysis of recent studies on magnetic fields and childhood leukaemia. Br J Cancer 2010;103:1128-35.

81. Swerdlow AJ. Health effects from radiofrequency electromagnetic fields. Didcot, Oxfordshire: National Radiological Protection Board; 2003.

82. Hatch EE, Linet MS, Kleinerman RA, Tarone RE, Severson RK, Hartsock CT, et al. Association between childhood acute lymphoblastic leukemia and use of electrical appliances during pregnancy and childhood. Epidemiology 1998;9:234-45.

83. Findlay RP, Dimbylow PJ. SAR in a child voxel phantom from exposure to wireless computer networks (Wi-Fi). Phys Med Biol 2010;55:N405-11.

84. Elliott P, Toledano M, Bennett J, Beale L, de Hoogh K, Best N, et al. Case-control Study of mobile phone base stations and early childhood cancers. Epidemiology 2011;22:S52-3.

85. Bellieni CV, Pinto I, Bogi A, Zoppetti N, Andreuccetti D, Buonocore G. Exposure to electromagnetic fields from laptop use of "laptop" computers. Arch Environ Occup Health 2012;67:31-6.

86. Petticrew M, Bell R, Hunter D. Influence of psychological coping on survival and recurrence in people with cancer: Systematic review. BMJ 2002;325:1066.

87. Mills GB. Genetic predisposition to cancer. In: Pollock RE, editor. Hoboken. $8^{\text {th }}$ ed. New Jersey, USA: John Wiley and Sons; 2004. p. 63-89.

88. Giordano S. Breast cancer in men. Ann Intern Med 2002;137:678.

89. Guray M, Sahin AA. Benign breast diseases: Classification, diagnosis, and management. Oncologist 2006;11:435-49.

90. Berry DA, Cronin KA, Plevritis SK, Fryback DG, Clarke L, Zelen M, et al. Effect of screening and adjuvant therapy on mortality from breast cancer. N Engl J Med 2005;353:1784-92.

91. Pharoah PD, Day NE, Duffy S, Easton DF, Ponder BA. Family history and the risk of breast cancer: A systematic review and meta-analysis. Int J Cancer 1997;71:800-9.

92. Tam Ashing K, Padilla G, Tejero J, Kagawa-Singer M. Understanding the breast cancer experience of Asian American women. Psychooncology 2003;12:38-58.

93. Antoniou A, Pharoah PD, Narod S, Risch HA, Eyfjord JE, Hopper JL, et al. Average risks of breast and ovarian cancer associated with BRCA1 or BRCA2 mutations detected in case series unselected for family history: A combined analysis of 22 studies. Am J Hum Genet 2003;72:1117-30.

94. Berg WA, Zhang Z, Lehrer D, Jong RA, Pisano ED, Barr RG, et al. Detection of breast cancer with addition of annual screening ultrasound or a single screening MRI to mammography in women with elevated breast cancer risk. JAMA 2012;307:1394-404.

95. Fisher B, Anderson S, Redmond CK, Wolmark N, Wickerham DL, Cronin WM. Reanalysis and results after 12 years of follow-up in a randomized clinical trial comparing total mastectomy with lumpectomy with or without irradiation in the treatment of breast cancer. N Engl J Med 1995;333:1456-61.

96. CDC - What Can I Do to Reduce My Risk of Breast Cancer? 2016. Available from: http://www.cdc.gov/cancer/breast/basic_info/ prevention.htm. [Last cited on 2016 Jul 07].

97. Chen L, Malone KE, Li Cl. Bra wearing not associated with breast cancer risk: A population-based case-control study. Cancer Epidemiol Biomarkers Prev 2014;23:2181-5.

98. Kasumi F. Problems in breast cancer screening. Jpn Med Assoc J 2005;48:301-9.

99. Caraceni A, Hanks G, Kaasa S, Bennett MI, Brunelli C, 
Cherny $\mathrm{N}$, et al. Use of opioid analgesics in the treatment of cancer pain: Evidence-based recommendations from the EAPC. Lancet Oncol 2012;13:e58-68.

100. Savage P. Development and economic trends in cancer therapeutic drugs in the UK from 1955 to 2009. J Oncol Pharm Pract 2012;18:52-6.

101. Roila F, Ruggeri B, Ballatori E, Del Favero A, Tonato M. Aprepitant versus dexamethasone for preventing chemotherapy-induced delayed emesis in patients with breast cancer: A randomized double-blind study. J Clin Oncol 2013;32:101-6.

102. Saito M. Review of palonosetron in the prevention of chemotherapy-induced nausea and vomiting. Clin Med Rev Oncol 2010;2:209-20.

103. Pui C, Jeha S, Irwin D, Camitta B. Recombinant urate oxidase (rasburicase) in the prevention and treatment of malignancy-associated hyperuricemia in pediatric and adult patients: Results of a compassionate-use trial. Leukemia 2001;15:1505-9.

104. Mor V, Stalker MZ, Gralla R, Scher HI, Cimma C, Park D, et al. Day hospital as an alternative to inpatient care for cancer patients: A random assignment trial. J Clin Epidemiol 1988;41:771-85.

105. Siegel RL, Miller KD, Jemal A. Cancer statistics, 2016. CA Cancer J Clin 2016;66:7-30.

106. Friedrichs K, Carstensen MH. Successful reduction of alopecia induced by anthracycline and taxane containing adjuvant chemotherapy in breast cancer - Clinical evaluation of sensor-controlled scalp cooling. Springerplus 2014;3:500.

107. Kouvaris JR, Kouloulias VE, Vlahos LJ. Amifostine: The first selective-target and broad-spectrum radioprotector. Oncologist 2007;12:738-47.

108. Choi M, Jiang PQ, Heilbrun LK, Smith DW, Gadgeel SM. Retrospective review of cancer patients $>$ or $=80$ years old treated with chemotherapy at a comprehensive cancer center. Crit Rev Oncol Hematol 2008;67:268-72.
109. Vento S, Cainelli F. Infections in patients with cancer undergoing chemotherapy: Aetiology, prevention, and treatment. Lancet Oncol 2003;4:595-604.

110. Lyman GH, Kuderer NM, Djulbegovic B. Prophylactic granulocyte colony-stimulating factor in patients receiving dose-intensive cancer chemotherapy: A meta-analysis. Am J Med 2002;112:406-11.

111. Zemlickis D, Lishner M, Degendorfer P, Panzarella T, Sutcliffe SB, Koren G. Fetal outcome after in utero exposure to cancer chemotherapy. Arch Intern Med 1992;152:573-6.

112. Cardonick $E$, lacobucci $A$. Use of chemotherapy during human pregnancy. Lancet Oncol 2004;5:283-91.

113. Loren AW, Mangu PB, Beck LN, Brennan L, Magdalinski AJ, Partridge $\mathrm{AH}$, et al. Fertility preservation for patients with cancer: American Society of Clinical Oncology clinical practice guideline update. J Clin Oncol 2013;31:2500-10.

114. Engzell U, Esposti PL, Rubio C, Sigurdson A, Zajicek J. Investigation on tumour spread in connection with aspiration biopsy. Acta Radiol Ther Phys Biol 1971;10:385-98.

115. Rao A, Cohen HJ. Symptom management in the elderly cancer patient: Fatigue, pain, and depression. J Natl Cancer Inst Monogr 2004;32:150-7.

116. Dimeo FC, Tilmann MH, Bertz H, Kanz L, Mertelsmann R, Keul J. Aerobic exercise in the rehabilitation of cancer patients after high dose chemotherapy and autologous peripheral stem cell transplantation. Cancer 1997;79:1717-22.

117. Herbert V. Unproven (questionable) dietary and nutritional methods in cancer prevention and treatment. Cancer 1986;58 8 Suppl: $1930-41$.

118. Schraub S. Unproven methods in cancer: A worldwide problem. Support Care Cancer 2000;8:10-5.

119. Wong YN, Mitra N, Hudes G, Localio R, Schwartz JS, Wan F, et al. Survival associated with treatment vs. observation of localized prostate cancer in elderly men. JAMA 2006;296:2683-93. 